Endokrynologia Polska

DOI: 10.5603/EP.a2016.0034

Tom/Volume 67; Numer/Number 3/2016

ISSN 0423-104X

\title{
Cushing's disease: Fibrinogen and D-dimer levels fail to normalise despite early postoperative remission a prospective, controlled study
}

\section{Choroba Cushinga: brak normalizacji stężeń fibrynogenu i D-dimerów u pacjentów z wczesną remisją hiperkortyzolemii — badanie prospektywne}

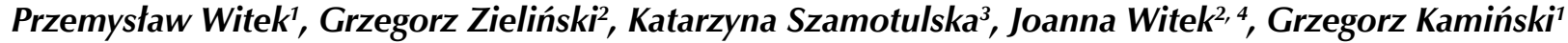 \\ ${ }^{1}$ Department of Endocrinology and Isotope Therapy, Military Institute of Medicine, Warsaw, Poland \\ ${ }^{2}$ Department of Neurosurgery, Military Institute of Medicine, Warsaw, Poland \\ ${ }^{3}$ Department of Epidemiology and Biostatistics, Institute of Mother and Child, Warsaw, Poland \\ ${ }^{4}$ Diabetes Outpatient Clinic, Institute of Mother and Child, Warsaw, Poland
}

\begin{abstract}
Introduction: Effective transsphenoidal surgery (TSS) for Cushing`s disease (CD) normalizes cortisol levels and reduces complications of hypercortisolism. However, there is evidence of increased cardiovascular morbidity even after successful surgery. Objective. A prospective, controlled study on the dynamics of fibrinogen and D-dimer levels with a six-month follow-up after an effective TSS for CD.

Material and methods: Forty patients with CD and forty healthy age- and sex-matched subjects were included. We assessed ACTH, urinary and serum cortisol, and fibrinogen and D-dimer levels before TSS and during follow-up.

Results: Baseline BMI $(\mathrm{P}<0.001)$, fibrinogen $(\mathrm{P}=0.002)$, and $\mathrm{D}$-dimer $(\mathrm{P}=0.001)$ levels in $\mathrm{CD}$ patients were significantly higher than those in healthy controls. High fibrinogen levels in the CD group were independent of BMI, and were positively associated with hsCRP $\left(r_{s}=0.61, P<0.001\right)$ and arterial hypertension $(P=0.029)$. After the six-month follow-up we confirmed a sustained difference between the remission group and controls in fibrinogen and D-dimer levels ( $P=0.001$ and $P=0.017$, respectively).

Conclusions: Despite early biochemical remission of $\mathrm{CD}$ the levels of fibrinogen and D-dimer failed to decrease. This probably contributes to the high risk of thrombotic events and indicates the need for a close follow-up for signs of thromboembolic and cardiovascular complications in patients with early CD remission. (Endokrynol Pol 2016; 67 (3): 283-291)

Key words: hypercortisolaemia; cortisol; Cushing's disease; fibrinogen; D-dimer level; transsphenoidal surgery; thromboembolic complications

\section{Streszczenie}

Wstęp: Skuteczne leczenie chirurgiczne choroby Cushinga prowadzi do normalizacji stężenia kortyzolu i redukcji powikłań hiperkortyzolemii. Istotnym spostrzeżeniem jest jednak fakt utrzymywania się zwiększonego ryzyka związanego z powikłaniami sercowo-naczyniowymi, nawet po skutecznym leczeniu operacyjnym.

Celem pracy była prospektywna ocena zmian stężenia fibrynogenu i D-dimerów w okresie 6 miesięcy po przeprowadzonym leczeniu chirurgicznym choroby Cushinga.

Materiał i metody: Do badania włączono 40 pacjentów dobranych pod względem płci i wieku z rozpoznaną chorobą Cushinga i 40 osób zdrowych. U badanych wykonano oznaczenia stężeń: ACTH, kortyzolu w moczu i surowicy, fibrynogenu i D-dimerów przed leczeniem chirurgicznym i w okresie obserwacji.

Wyniki: Wartości BMI $(\mathrm{P}<0,001)$, fibrynogenu $(\mathrm{P}=0,002)$ i D-dimerów $(\mathrm{P}=0,001)$ były istotnie wyższe w grupie pacjentów z choroba Cushinga $\mathrm{w}$ porównaniu ze zdrowymi osobami. Wysokie stężenie fibrynogenu wśród pacjentów z chorobą Cushinga było niezależne od wartości BMI, ale wykazywało dodatnią zależność od wartości hsCRP $\left(\mathrm{r}_{\mathrm{S}}=0,61, \mathrm{P}<0,001\right)$ i występowania nadciśnienia tętniczego $(\mathrm{P}=0,029)$. Potwierdzono utrzymywanie się istotnej różnicy stężeń fibrynogenu i $\mathrm{D}$-dimerów $(\mathrm{P}=0,001$ i $\mathrm{P}=0,017$, odpowiednio) po 6 miesiącach od operacji pomiędzy chorymi, u których uzyskano remisję hiperkortyzolemii i osobami zdrowymi.

Wnioski: Mimo wczesnej remisji hiperkortyzolemii w chorobie Cushinga, stężenia fibrynogenu i D-dimerów nie ulegają obniżeniu. Prawdopodobnie jest to przyczyną wysokiego ryzyka incydentów zakrzepowo-zatorowych u tych chorych, a także wskazanie do ścisłej obserwacji pooperacyjnej chorych w okresie remisji. (Endokrynol Pol 2016; 67 (3): 283-291)
\end{abstract}

Słowa kluczowe: hiperkortyzolemia; kortyzol; choroba Cushinga; fibrynogen, D-dimery; operacja przezklinowa; powikłania zakrzepowo-zatorowe 


\section{Introduction}

Cushing's Disease (CD) is the most common cause of ACTH-dependent hypercortisolaemia. Transsphenoidal selective adenomectomy (TSS), performed by an experienced neurosurgeon, remains the treatment of choice. CD-related hypercortisolism leads to the development of cardiovascular and metabolic complications, which increases both cardiovascular morbidity and mortality, often lowering quality of life [1-6]. Successful surgical treatment results in normalisation of hypothalamicpituitary axis parameters, improves clinical signs and symptoms, and reduces hypercortisolism-related complications, such as hypertension or diabetes. However, elevated cardiovascular risk has been demonstrated to persist for up to five years following successful surgical treatment $[7,8]$. This persisting cardiovascular risk as well as the estimated $15-20 \%$ recurrence rate require a long-lasting postoperative follow-up [1-4, 7].

Chronic hypercortisolism, which is the essence of $\mathrm{CD}$, as well as the glucocorticoids used in drug therapy lead to blood coagulation abnormalities by increasing the incidence of venous thromboembolism and accelerating the development of atherosclerosis. The hypercoagulable state can lead to increased incidence of thromboembolic episodes in the postoperative period or during diagnostic procedures such as inferior petrosal sinus sampling [9-14]. Boscaro et al. demonstrated significantly higher thromboembolic mortality and morbidity in a group of Cushing's syndrome patients receiving no anti-thromboembolic prevention in comparison with those in a group receiving prophylactic treatment with the use of warfarin or heparin [14].

There is still a need for prospective, controlled studies on the role of individual coagulation parameters and the changes in their levels following successful pituitary surgery for $\mathrm{CD}$. The purpose of this study was to prospectively evaluate the levels of fibrinogen and Ddimers, the changes of these parameters over a period of six months (early remission), and their association with characteristics specific to CD in a homogeneous group of patients following successful transsphenoidal corticotropinoma resection.

\section{Material and methods}

\section{Patient population}

The study population consisted of 40 consecutive patients with Cushing's disease (32 women and 8 men; F:M ratio: 4:1) hospitalised in the Department of Endocrinology and operated on in the Department of Neurosurgery of the Military Institute of Medicine in Warsaw between 2013 and 2015. The mean age of the study group was $42.4 \pm 15.7$ years (range: $17-79$ years).
After confirmed diagnosis of Cushing s disease the patients were operated on by the same neurosurgeon using the same surgical protocol. The control group comprised 40 healthy sex- and age-matched volunteers at the mean age of $42.9 \pm 14.3$ years (range: $21-79$ years).

All patients were informed about the aims and methods of the study and they each signed the informed consent. The study protocol was approved by the Ethics Committee at the Military Institute of Medicine in Warsaw.

\section{Preoperative endocrine and coagulation assessment}

All patients underwent a standard clinical evaluation with an assessment of BMI, any history of hypertension, and glucose homeostasis alterations. The diagnosis of ACTH-dependent Cushing's syndrome (CS) was made based on the clinical signs and standard hormonal criteria: increased urinary free cortisol (UFC), increased morning serum cortisol levels at 8.00, loss of cortisol circadian rhythm (the serum cortisol level above $7.5 \mu \mathrm{g} / \mathrm{dL}$ in the late-night hours (22.00-00:00)), increased or detectable plasma ACTH levels at 8.00, and failure to suppress serum cortisol levels to less than or equal to $1.8 \mu \mathrm{g} / \mathrm{dL}$ during an overnight dexamethasone suppression test (ODST; $1 \mathrm{mg}$ at midnight). The pituitary aetiology of CS was confirmed based on serum cortisol or UFC suppression greater than $50 \%$ with a high-dose dexamethasone suppression test (HDDST; 2 mg q.i.d. for 48 hours) and positive pituitary MRI. In cases of inconclusive hormonal assessment and pituitary imaging the diagnosis of $\mathrm{CD}$ was confirmed by a positive result of a stimulation test with intravenous CRHinjection $(100 \mu \mathrm{g})$ and/or results of inferior petrosal sinus sampling (IPSS). As well as the standard hormonal assessment, all patients had blood samples taken for testing fibrinogen, D-dimer, and hsCRP levels. These blood samples were collected in the fasting state from the antecubital vein into test tubes with $3.2 \%$ sodium citrate (fibrinogen and D-dimer) and with clotting activator (hsCRP) between 07:00 and 08:00 and centrifuged for 15 minutes at 2000 grams or 10 minutes at 1500 grams, respectively.

\section{Preoperative MRI}

Prior to neurosurgical treatment all patients underwent high-resolution magnetic resonance imaging of the pituitary-hypothalamic region (GE Signa, 1.5 Tesla), performed before and after intravenous injection of gadolinium (Gd-DTPA). Any hypodense lesion visualised after contrast administration was considered to be indicative of pituitary adenoma. Microadenoma was defined as a pituitary tumour with a diameter of less than $1 \mathrm{~cm}$, whereas macroadenoma was defined as a tumour with at least one diameter of more than $1 \mathrm{~cm}$. 


\section{Surgical procedure}

A microsurgical transseptal transsphenoidal approach was used for resection of an ACTH-secreting pituitary adenoma. The pituitary gland was carefully examined, regardless of MRI findings. Selective adenomectomy was performed in all cases of MRI-visualised pituitary adenomas. Where MRI findings were inconclusive or no tumour was evident, a series of vertical and horizontal incisions of the pituitary gland were performed and all tissue that was deemed abnormal was removed and submitted for pathological examination.

\section{Postoperative hormonal evaluation and criteria of cure}

Blood samples for serum cortisol measurements were collected from all patients at 06:00 on the first postoperative day. Glucocorticoids were not administered in the perioperative or in the early postoperative period. Hydrocortisone replacement therapy was started after biochemical confirmation of hypercortisolaemia or the development of clinical manifestations of adrenal insufficiency. The standard dose of hydrocortisone (20 $\mathrm{mg}$ in the morning and $10 \mathrm{mg}$ at 15.00 ) was introduced when necessary and continued until the next hormonal evaluation.

Following the surgical procedure, all patients were subjected to further postoperative evaluation. Subsequent reassessments of hormonal and coagulation parameters were performed at three and six months after pituitary surgery. Patients on hydrocortisone replacement therapy had their cortisol measurements taken 48 hours after the last administered dose. We used the following criteria for early remission: clinical and biochemical evidence of adrenal insufficiency or, in the case of preserved adrenal function, biochemical evidence of eucortisolaemia: UFC, morning serum cortisol and plasma ACTH levels within their respective reference ranges, preserved circadian rhythm of serum cortisol (the late night serum cortisol level $\leq 7.5$ $\mu \mathrm{g} / \mathrm{dL}$ ), and ODST-induced serum cortisol suppression to $\leq 1.8 \mu \mathrm{g} / \mathrm{dL}$.

\section{Laboratory assays}

Human adrenocorticotropic hormone (ACTH) levels were assessed using solid-phase, two-site immunoradiometric assay (IRMA ELSA-ACTH, CIS bio International, France). The analytical sensitivity was $2 \mathrm{pg} / \mathrm{mL}$ (reference range: 10-60 pg/mL). Serum cortisol concentrations were determined by electrochemiluminescence immunoassay (ECLIA) (Elecsys 2010, Roche Diagnostics, Switzerland). Analytical sensitivity was $0.02 \mu \mathrm{g} / \mathrm{dL}$ (reference range in the morning: 6.2-19.4 $\mu \mathrm{g} / \mathrm{dL}$; in the afternoon: $2.3-11.9 \mu \mathrm{g} / \mathrm{dL}$ ). Urinary cortisol after extraction (dichloromethane) was measured by coated- tube radioimmunoassay (RIA) kits (Cortisol RIA kit, Immunotech, Czech Republic). Analytical sensitivity was $1.8 \mu \mathrm{g}$. The reference range was $13.7-75.3 \mu \mathrm{g} / 24 \mathrm{hr}$. D-dimer levels were measured via an automated immunoturbidimetric method with polystyrene latex beads (HemosIL D-Dimer HS 500). The cut-off point was $0.5 \mu \mathrm{g} / \mathrm{mL}$ and method sensitivity was $0.215 \mu \mathrm{g} / \mathrm{mL}$. Fibrinogen levels were measured via Clauss method using a Q.F.A. thrombin kit. The reference range was 200-393 mg/dL. Serum fibrinogen and D-dimer levels were measured with an ACL TOP 500 CTS analyser (Instrumentation Laboratory, a Werfen Company). Blood hsCRP levels were measured by immunonephelometry with a BN ProSpec ${ }^{\circledR}$ System analyser (Siemens Healthcare, Germany). The cut-off point was $2.87 \mathrm{mg} / \mathrm{L}$ and method sensitivity was $0.175 \mathrm{mg} / \mathrm{L}$.

\section{Statistical analysis}

Methods of descriptive statistics (mean, median, standard deviation, range, interquartile range, proportion) were employed in the statistical analysis. The hypotheses concerning the relationship between two variables were verified using the exact chi-square test (Fisher's exact test) for categorical characteristics and test for Spearman's correlation coefficient $\left(r_{s}\right)$ for continuous parameters. The significance of the differences between average values of continuous variables in two groups was analysed by means of the t-Student test for normally distributed data and the Mann-Whitney test for non-normally distributed data. Multiple linear regression was applied to study the relationship between one continuous dependent variable and two independent variables. Verification of hypotheses concerning comparisons of the continuous parameters in two time points was conducted using paired $t$-Student test or the Wilcoxon test depending on assumptions. The level of significance was set at $\mathrm{P}<0.05$. All calculations were made using the commercially available statistical software package IBM SPSS v. 22.

\section{Results}

\section{Preoperative characteristics}

Table I presents a comparison of demographic data, body mass index (BMI), the levels of fibrinogen, Ddimers, hsCRP, serum cortisol, and plasma ACTH obtained in the preoperative period from 40 patients with Cushing's disease (CD) against the analogous parameters obtained from the control group of healthy volunteers matched for sex and age.

The CD group was additionally evaluated for other routinely assessed hormonal parameters of the pituitary-adrenal axis. Median UFC excretion in 24-hour urine collection was $285.4 \mu \mathrm{g} / \mathrm{dL}$ (IQR 190.5-450.5), the mean midnight serum cortisol level was $17.2 \pm 6.6 \mu \mathrm{g} /$ 
Table I. Preoperative characteristics of Cushing disease patients and the control group Tabela I. Przedoperacyjna charakterystyka pacjentów z chorobą Cushinga i grupy kontrolnej

\begin{tabular}{lccc}
\hline & Cases $\mathbf{( n = 4 0 )}$ & Controls $(\mathbf{n}=\mathbf{4 0})$ & P-value \\
\hline Age (years, mean $\pm \mathrm{SD})$ & $42.4 \pm 15.7$ & $42.9 \pm 14.3$ & 0.897 \\
\hline Women $(\%)$ & $80.0 \%$ & $80.0 \%$ & 1.000 \\
\hline BMI $\left[\mathrm{kg} / \mathrm{m}^{2}\right.$, mean $\left.\pm \mathrm{SD}\right]$ & $30.8 \pm 6.8$ & $24.2 \pm 3.5$ & $<0.001$ \\
\hline Cortisol $[\mu \mathrm{g} / \mathrm{dL}$, median, IQR] & $22.2(17.0-31.5)$ & $12.3(10.0-17.4)$ & $<0.001$ \\
\hline ACTH $[\mathrm{pg} / \mathrm{mL}$, median, IQR & $73.5(46.7-96.1)$ & $16.6(11.0-23.3)$ & $<0.001$ \\
\hline D-dimer $[\mu \mathrm{g} / \mathrm{mL}$, median, IQR] & $0.485(0.293-0.873)$ & $0.320(0.195-0.435)$ & 0.002 \\
\hline Fibrynogen $[\mathrm{mg} / \mathrm{dL}$, mean $\pm \mathrm{SD}$ & $334.2 \pm 74.3$ & $278.1 \pm 65.3$ & 0.001 \\
\hline hsCRP $[\mathrm{mg} / \mathrm{dL}$, median, IQR] & $0.125(0.040-0.375)$ & $0.095(0.040-0.200)$ & 0.668 \\
\hline
\end{tabular}

$/ \mathrm{dL}$, and the median cortisol level following an overnight dexamethasone suppression test was $12.9 \mu \mathrm{g} / \mathrm{dL}$ (IQR 6.6-22.1).

Magnetic resonance imaging (MRI) revealed a pituitary microadenoma in 33 patients $(83 \%)$ and a macroadenoma in 7 patients $(17 \%)$ with CD.

Hypertension, a known complication of hypercortisolism, was diagnosed in 30 patients $(75 \%)$ from the CD group. Glucose metabolism disorders were found in 29 patients $(72.5 \%)$ from the CD group. Diagnostic criteria for diabetes were met by 11 patients $(27.5 \%)$ and the criteria for pre-diabetes by 18 patients $(45 \%)$.

Then, the study group was evaluated for relationships between levels of fibrinogen, D-dimers against demographic, anthropometric, hormonal, and biochemical parameters. No significant correlation was found between fibrinogen levels and the age of CD patients $\left(r_{S}=0.21 ; P=0.202\right)$. However, there was a positive correlation between $\mathrm{D}$-dimer levels and age in this group $\left(r_{\mathrm{S}}=0.34 ; \mathrm{P}=0.035\right)$. Our findings suggested a positive correlation between serum fibrinogen levels and BMI in the study group $\left(r_{\mathrm{S}}=0.28 ; \mathrm{P}=0.084\right)$. Such a correlation was not observed in the case of D-dimers $\left(r_{S}=0.13\right.$; $\mathrm{P}=0.424$ ). Subsequently, a multivariate linear regression model was used to analyse the impact of BMI on the difference in fibrinogen concentration between $\mathrm{CD}$ and the control group. This analysis revealed the fibrinogen levels to be significantly higher in the CD group $(\beta=43.3 ; \mathrm{P}=0.023)$, irrespective of $\mathrm{BMI}$ values $(\beta=2.1 ; \mathrm{P}=0.159)$. No significant correlation was observed between fibrinogen levels and serum cortisol levels at 08:00 $\left(\mathrm{r}_{\mathrm{S}}=0.01 ; \mathrm{P}=0.973\right)$, at midnight $\left(\mathrm{r}_{\mathrm{S}}=-0.03\right.$; $\mathrm{P}=0.852)$, following an ODST $\left(\mathrm{r}_{\mathrm{S}}=0.10 ; \mathrm{P}=0.538\right)$, or UFC levels $\left(r_{\mathrm{s}}=-0.25 ; \mathrm{P}=0.114\right)$. Similarly, no correlation was demonstrated between D-dimer levels and the above hormonal parameters, with the corresponding Spearman's rho values of $0.11(\mathrm{P}=0.511),-0.03(\mathrm{P}=0.860)$, $-0.16(\mathrm{P}=0.339)$, and $-0.09(\mathrm{P}=0.587)$, respectively. However, the tests demonstrated a positive correla- tion between fibrinogen and hsCRP levels both in the CD group $\left(\mathrm{r}_{\mathrm{S}}=0.61 ; \mathrm{P}<0.001\right)$ and in the control group $\left(\mathrm{r}_{\mathrm{S}}=0.56 ; \mathrm{P}<0.001\right)$. The correlation between plasma D-dimer levels and serum hsCRP levels in the $\mathrm{CD}$ group showed borderline statistical significance $\left(r_{\mathrm{S}}=0.31 ; \mathrm{P}=0.054\right)$. The mean fibrinogen level in the study group was shown to be significantly higher in the hypertensive patients than that in the normotensive individuals (347.7 vs. 293.8; $\mathrm{P}=0.029$ ). However, there were no significant differences between mean plasma $\mathrm{D}$-dimer levels in the hypertensive and normotensive subgroups $(0.49 \mu \mathrm{g} / \mathrm{mL}$ vs. $0.43 \mu \mathrm{g} / \mathrm{mL} ; \mathrm{P}=0.662)$. The diabetic and non-diabetic patient subgroups showed no differences in terms of mean fibrinogen levels (346.7 mg/dL vs. $329.5 \mathrm{mg} / \mathrm{dL} ; \mathrm{P}=0.515$ ) or median D-dimer levels $(0.53 \mu \mathrm{g} / \mathrm{mL}$ vs. $0.45 \mu \mathrm{g} / \mathrm{mL} ; \mathrm{P}=0.820)$.

\section{Results of surgical treatment and perioperative assessment}

A total of 40 study patients underwent surgical treatment. In 38 cases (95\%) it was the first-time surgical treatment, while 2 patients $(5 \%)$ underwent a transsphenoidal surgery for the second time. Six months after surgery, early CD remission (based on pre-determined criteria) was confirmed in 32 patients $(80 \%$ ), while the remaining 8 patients (20\%) were diagnosed with persistent hypercortisolism. Median nadir serum cortisol on postoperative day 1 was $1.3 \mu \mathrm{g} / \mathrm{dL}$ (IQR: 0.72-4.45) for the whole study group. In the remission and persistent hypercortisolism subgroups the median nadir cortisol levels were $0.995 \mu \mathrm{g} / \mathrm{dL}$ and 12.600 $\mu \mathrm{g} / \mathrm{dL}$, respectively $(\mathrm{P}<0.001)$.

\section{Postoperative assessment of the evaluated parameters}

Table II shows detailed postoperative results of hormonal parameters, fibrinogen, D-dimer levels, as well as BMI values in the remission group $(\mathrm{n}=32)$. These parameters were evaluated 3 and 6 months after surgery. Additionally, Figure 1 and 2 illustrate the changes in serum cortisol 
Table II. Dynamics of hormonal parameters, BMI, fibrinogen, and D-dimer before $\left(t_{0}\right), 3$ months $\left(t_{3}\right)$, and 6 months $\left(t_{6}\right)$ after surgery in Cushing disease patients in early remission $(n=32)$

Tabela II. Zmiany wyników badań hormonalnych, BMI, fibrynogenu, D-dimerów przed $\left(t_{0}\right)$, 3 miesiq̨ce $\left(t_{3}\right)$ i 6 miesięcy $\left(t_{6}\right)$ po skutecznej operacji przezklinowej z powodu choroby Cushinga $(n=32)$

\begin{tabular}{lcccccc}
\hline & $\begin{array}{c}\text { ACTH [pg/mL] } \\
\text { median (IOR) }\end{array}$ & $\begin{array}{c}\text { Cortisol }[\mu \mathrm{g} / \mathrm{dL}] \\
\text { median (IOR) }\end{array}$ & $\begin{array}{c}\text { UFC }[\mu \mathrm{g} / 24 \mathrm{~h}] \\
\text { median (IOR) }\end{array}$ & $\begin{array}{c}\text { BMI [kg/m²] } \\
\text { mean } \pm \text { SD }\end{array}$ & $\begin{array}{c}\text { Fibrinogen [mg/dL] } \\
\text { mean } \pm \text { SD }\end{array}$ & $\begin{array}{c}\text { D-dimer }[\mu \mathrm{g} / \mathrm{mL}] \\
\text { median (IOR) }\end{array}$ \\
\hline $\mathrm{t}_{0}$ & $68.4(45.1-88.0)$ & $21.6(16.3-31.4)$ & $294.0(204.1-461.0)$ & $31.2 \pm 7.1$ & $325.4 \pm 75.4$ & $0.430(0.293-0.793$ \\
\hline $\mathrm{t}_{3}$ & $9.7(7.0-14.5)$ & $1.1(0.4-4.2)$ & $6.6(2.2-13.5)$ & $29.6 \pm 6.9$ & $327.7 \pm 75.6$ & $0.605(0.450-0.950)$ \\
\hline $\mathrm{t}_{6}$ & $11.3(8.4-16.4)$ & $2.3(0.8-6.8)$ & $13.0(2.8-31.0)$ & $27.9 \pm 6.2$ & $343.8 \pm 91.6$ & $0.425(0.263-0.708)$ \\
\hline $\mathrm{P}\left(\mathrm{t}_{3}\right.$ vs. $\left.\mathrm{t}_{0}\right)$ & $<0.001$ & $<0.001$ & $<0.001$ & $<0.001$ & 0.875 & 0.056 \\
\hline $\mathrm{P}\left(\mathrm{t}_{6}\right.$ vs. $\left.\mathrm{t}_{3}\right)$ & 0.137 & 0.027 & $<0.001$ & $<0.001$ & 0.203 & 0.001 \\
\hline $\mathrm{P}\left(\mathrm{t}_{6}\right.$ vs. $\left.\mathrm{t}_{0}\right)$ & $<0.001$ & $<0.001$ & $<0.001$ & $<0.001$ & 0.230 & 0.765 \\
\hline
\end{tabular}

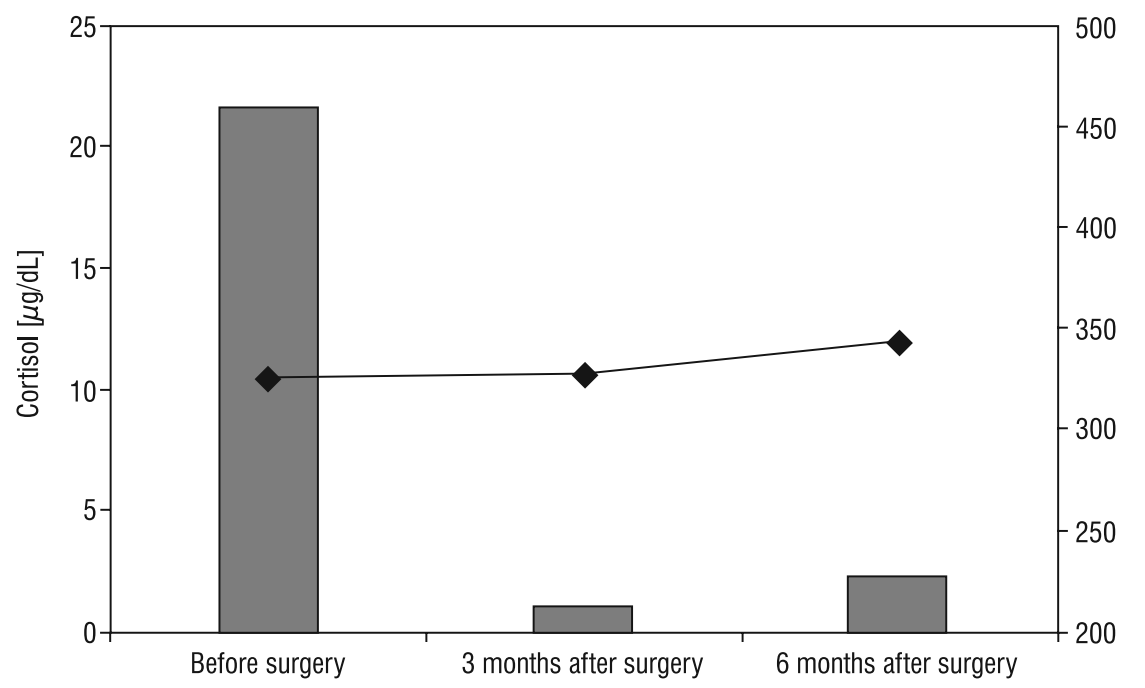

Figure 1. Median concentration of serum cortisol and mean fibrinogen levels after TSS in CD patients in early remission ( $n=32)$

Rycina 1. Mediana stężenia kortyzolu w surowicy i średnie stężenia fibrynogenu u pacjentów poddanych skutecznej operacji przezklinowej z powodu choroby Cushinga $(n=32)$

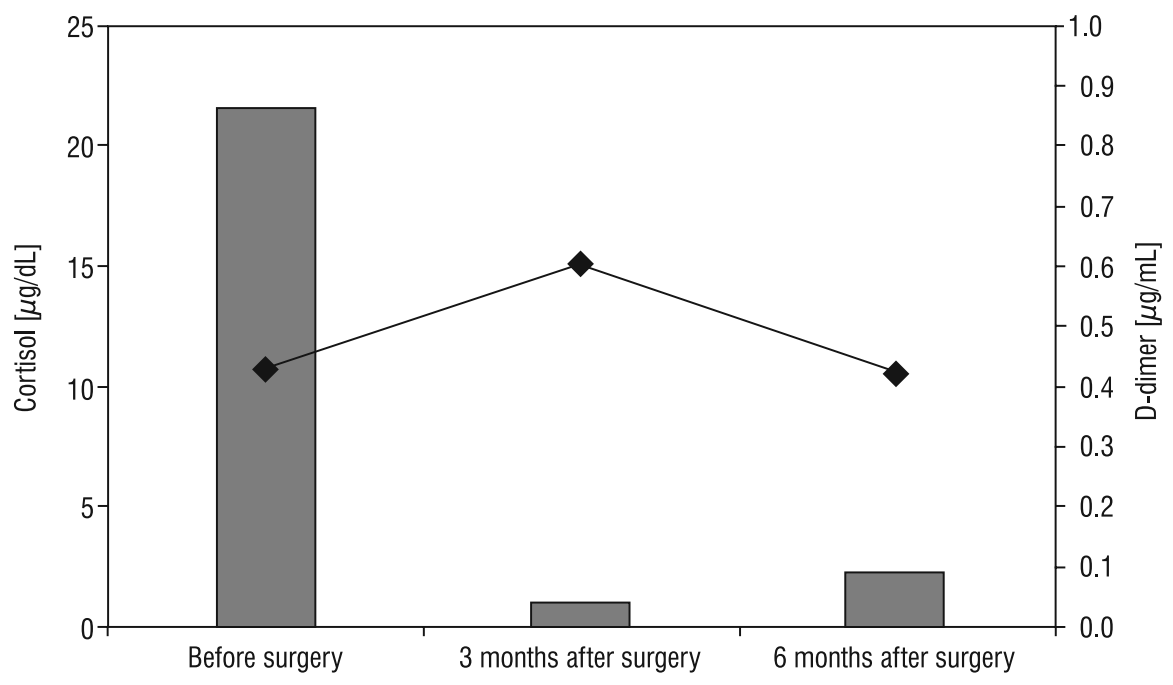

Figure 2. Median concentration of serum cortisol and median plasma D-dimer levels after surgery in Cushing disease patients in early remission $(n=32)$

Rycina 2. Mediana stężenia kortyzolu w surowicy i mediana stężenia D-dimerów po skutecznej operacji przezklinowej z powodu choroby Cushinga $(n=32)$ 
and plasma fibrinogen levels as well as serum cortisol and plasma D-dimer levels in the remission group.

The smaller $(n=8)$ group of patients with persistent hypercortisolaemia (lack of remission) had a median preoperative 08:00 serum cortisol level of $23.8 \mu \mathrm{g} / \mathrm{dL}$ (range: 12.0-69.7), whereas three and six months after surgery the levels were $18.5 \mu / \mathrm{dL}$ (range: 11.9-33.8) and $17.4 \mu \mathrm{g} / \mathrm{dL}$ (range: 13.3-57.6), respectively. The median preoperative plasma ACTH level was $108.2 \mathrm{pg} / \mathrm{mL}$ (range: 46.6-563.0), and three and six months postoperatively: $51.3 \mathrm{pg} / \mathrm{mL}$ (range: $31.4-215.2$ ) and $46.3 \mathrm{pg} / \mathrm{mL}$ (range: 5.9-290.1), respectively. The preoperative median urinary free cortisol in the group with persistent hypercortisolism was $258.2 \mu \mathrm{g} / 24 \mathrm{~h}$ (range: 134.4-552.0), 3 and 6 months after the surgery: $91.3 \mu \mathrm{g} / 24 \mathrm{~h}$ (range: 57.6-670.8) and $117.4 \mu \mathrm{g} / 24 \mathrm{~h}$ (range: $41.3-815.3$ ), respectively. The mean preoperative fibrinogen level in the persistent CD group was $369.5 \mathrm{mg} / \mathrm{dL}$ (range: $243-441$ ), and three and six months after surgery: $367.8 \mathrm{mg} / \mathrm{dL}$ (range: 299-443) and $367.4 \mathrm{mg} / \mathrm{dL}$ (range: 306-417), respectively. The median preoperative $\mathrm{D}$-dimer level in the persistent hypercortisolism group was $0.575 \mu \mathrm{g} / \mathrm{mL}$ (range: 0.200-0.950), and three and six months after surgery: $0.455 \mu \mathrm{g} / \mathrm{mL}$ (range: $0.260-1.140$ ) and $0.440 \mu \mathrm{g} / \mathrm{mL}$ (range: $0.260-1.400$ ), respectively.

Then, plasma fibrinogen and D-dimer levels in the CD remission subgroup measured preoperatively, three and six months after a successful TSS were compared with these parameters in the control group. The mean preoperative fibrinogen level in the $\mathrm{CD}$ remission group and fibrinogen level in the control group were $325.44 \pm$ $\pm 75.38 \mathrm{mg} / \mathrm{dL}$ vs. $278.1 \pm 65.3 \mathrm{mg} / \mathrm{dL}$, respectively $(\mathrm{P}=0.006)$. Mean fibrinogen levels in the $\mathrm{CD}$ remission group three and six months after surgery in comparison with the corresponding fibrinogen levels in the control group were $327.7 \pm 75.6 \mathrm{mg} / \mathrm{dL}$ vs. $278.1 \pm 65.3 \mathrm{mg} / \mathrm{dL}$ $(\mathrm{P}=0.004)$ and $343.8 \pm 91.5 \mathrm{mg} / \mathrm{dL} v s .278 .1 \pm 65.3 \mathrm{mg} / \mathrm{dL}$ $(\mathrm{P}=0.001)$, respectively. Similarly, median $\mathrm{D}$-dimer levels in the remission group measured before surgery, three and six months after transsphenoidal surgery in comparison with the control group were $0.430 \mu \mathrm{g} / \mathrm{mL}$ (IQR 0.293-0.793) vs. $0.320 \mu \mathrm{g} / \mathrm{mL}$ (IQR 0.195-0.435), $\mathrm{P}=0.005 ; 0.605 \mu \mathrm{g} / \mathrm{mL}$ (IQR $0.450-0.950)$ vs. 0.320 (IQR 0.195-0.435), $\mathrm{P}<0.001$; and $0.425 \mu \mathrm{g} / \mathrm{mL}$ (IQR 0.263-0.708) vs. 0.320 (IQR 0.195-0.435), $\mathrm{P}=0.017$, respectively. Figure 3 and 4 show a comparison of the remission group, persistent disease group, the control group in terms of fibrinogen, and D-dimer levels at the end of six-month follow-up.

\section{Discussion}

The rate of symptomatic thromboembolic complications following surgical procedures in the general population is approximately $1 \%$. However, in the case of major high-risk orthopaedic (e.g. total hip replacement), neurosurgical, urological procedures the rate is higher at $2-3 \%[15,16]$. In a meta-analysis of 15 studies evaluating the effect of endogenous hypercortisolism on coagulation and fibrinolysis abnormalities, Van Zaane et al. estimated the risk of venous thromboembolism (VTE) not provoked by surgery to be $1.9-2.5 \%$, while postoperative VTE rates ranged from 0 to 5.6\% [10]. Manetti et al. reported VTE in $7.5 \%$ of patients with Cushing's syndrome, while Boscaro reported VTE in up to $4.4 \%$ of patients, despite postoperative antithrombotic prophylaxis $[9,14]$. These results suggest that the CD population has a dramatically higher risk of VTE episodes than the general population.

Our study was a prospective evaluation of changes in fibrinogen (a cardiovascular risk marker and a coagulation factor) as well as D-dimer levels (a marker of coagulation and fibrinolysis system activation) in a homogeneous group of 40 patients with $\mathrm{CD}$ before pituitary surgery, three and six months after TSS.

Fibrinogen, has been classified as an acute phase protein, an established independent risk factor of cardiovascular and cerebrovascular disease [17, 18]. High fibrinogen levels have been observed in patients with myocardial infarction, stroke, and transient ischaemic attacks, i.e. in conditions characterised by an undeniable thrombotic aspect [18-21]. Fibrinogen levels have been demonstrated to be higher with age, in smokers, in the obese, in diabetes, and in hypertension [18, 19]. Fibrinogen is very likely to be a mediator of the prothrombotic effect of other cardiovascular risk factors $[17,18,22]$. The pathophysiological mechanisms involved in this effect include its impact on platelet aggregation and vascular endothelial function. Fibrinogen also affects the fluidity of blood by increasing blood viscosity and platelet aggregation [18-21, 23].

Our study demonstrated significantly higher fibrinogen levels in the group of patients with $\mathrm{CD}$ in comparison with those in the sex- and age-matched control group. An increase of fibrinogen levels in CD patients had already been reported in the scant literature on the subject $[9,24]$. At the same time, we did not demonstrate any correlation between fibrinogen levels and patient age, serum cortisol levels, and urinary free cortisol levels (UFC), which are the hormonal parameters routinely evaluated in laboratory diagnostic tests for hypercortisolism. Moreover, we demonstrated no association between fibrinogen levels and the rates of hypertension or carbohydrate metabolism in the study group.

However, we would like to emphasise the observed positive correlation between fibrinogen and hsCRP levels. This is consistent with the association between 


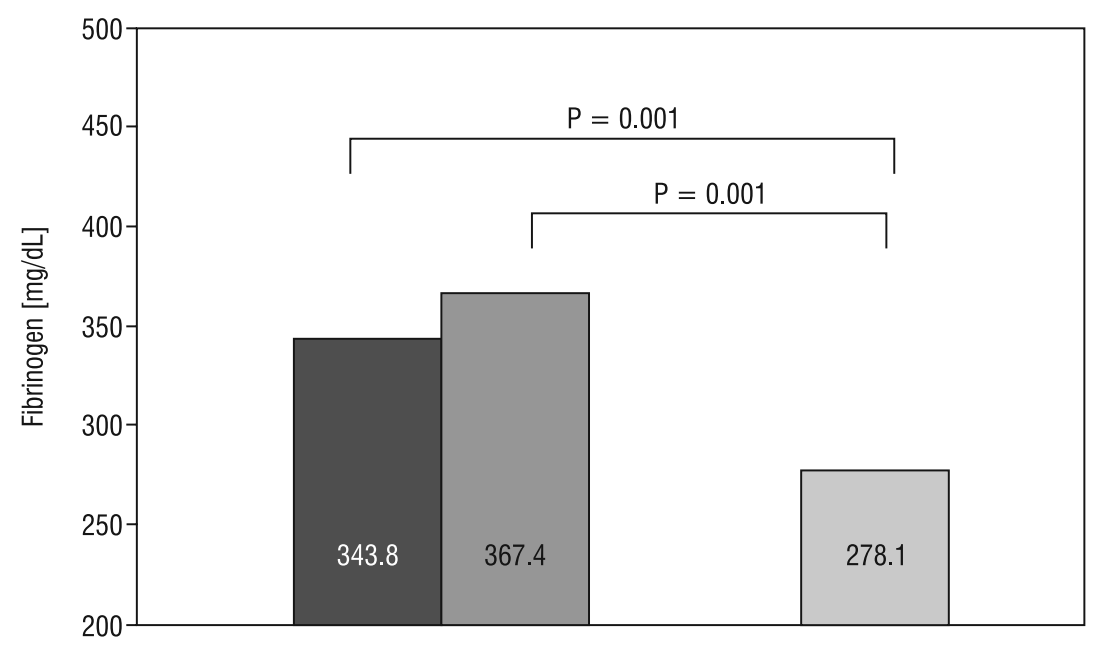

Figure 3. Concentration of plasma fibrinogen 6 months after surgery in Cushing disease patients in early remission $(n=32)$ and with persistent $C D(n=8)$ in comparison to the control group $(n=40)$

Rycina 3. Stężenie fibrynogenu po 6 miesiacach od operacji przezklinowej z powodu choroby Cushinga u pacjentów w okresie wczesnej remisji $(n=32)$ i pacjentów z przetrwałą chorobą $(n=8)$ w porównaniu z grupą kontrolną $(n=40)$

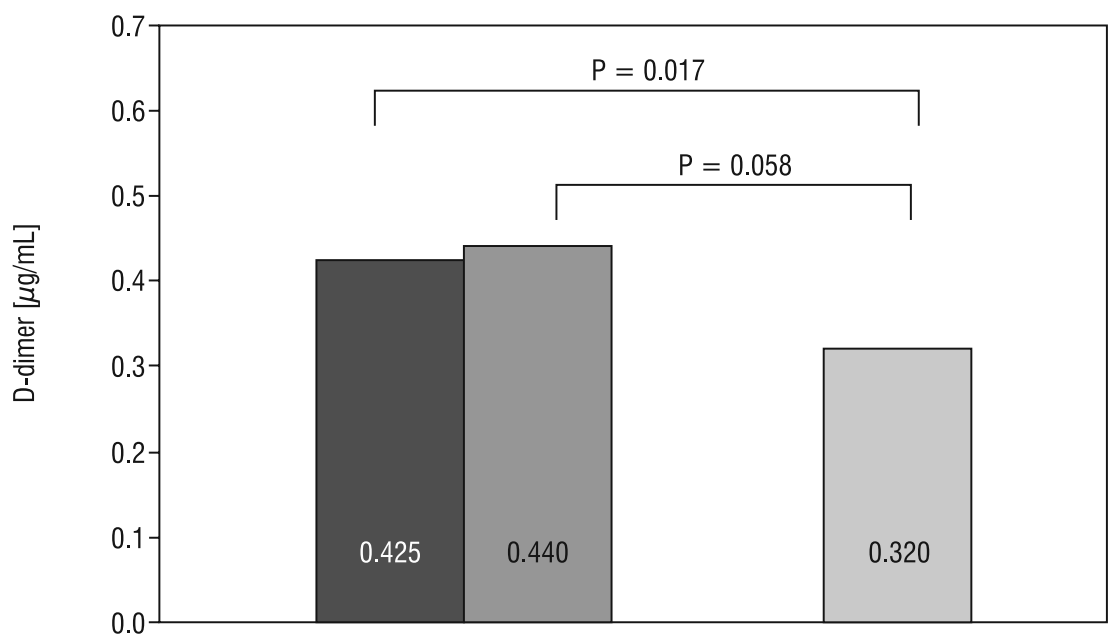

Figure 4. Concentration of plasma D-dimer 6 months after surgery in Cushing disease patients in early remission $(n=32)$ and with persistent $C D(n=8)$ in comparison to the control group $(n=40)$

Rycina 4. Stężenie D-dimerów po 6 miesiącach od operacji przezklinowej z powodu choroby Cushinga u pacjentów w okresie wczesnej remisji $(n=32)$ i pacjentów z przetrwatą chorobą $(n=8)$ w porównaniu z grupą kontrolnq $(n=40)$

these two acute phase proteins demonstrated in the general population, indicating the coexistence of inflammation and the state of thrombotic readiness also in patients with CD $[22,25,26]$. Thus, finding concomitantly elevated fibrinogen and hsCRP levels might help identify patients with high cardiovascular risk not only in the general population but also among patients with $\mathrm{CD}$. This, however, requires further studies with a larger number of patients and a longer postoperative follow-up period.

The association between fibrinogen levels and body mass index (BMI) also seems to be important.
We demonstrated both significantly higher fibrinogen levels and significantly higher BMI values in the group of $\mathrm{CD}$ patients in comparison with those in the control group. These findings are consistent with those by van der Pas et al. [11]. However, in our study we confirmed in multivariate analysis that the differences in BMI do not fully explain the higher fibrinogen levels in $C D$ patients comparatively to controls.

An important finding demonstrated in our study was the persistently higher fibrinogen levels throughout the six months following a successful surgical treatment, in comparison with the control group. This 
phenomenon occurred despite the achieved normalisation in terms of hormonal parameters of the pituitaryadrenal axis. Fibrinogen levels did not only remain significantly higher than those in the control group, but also remained higher than the baseline preoperative levels. The absence of a decrease in fibrinogen levels despite significant body mass reduction is another piece of evidence that this cardiovascular risk factor and the marker of thrombotic readiness are at least partially independent of the BMI. This fact seems to confirm, especially in light of the evidence gathered from the general population, the importance of fibrinogen. The risk of cardiovascular and thromboembolic events can still be elevated despite successful surgical treatment.

Our study also analysed the role of D-dimer levels as a marker of coagulation-fibrinolysis system activation. D-dimers are final products of plasmin-mediated degradation of fibrin found within a thrombus and stabilised by cross-links between fibrin chains. Plasma D-dimer levels are a marker of increased activity of the coagulation system and the secondary fibrinolysis [27]. Therefore, increased plasma D-dimer levels indirectly correlate with increased generation of thrombin, which catalyses the conversion of fibrinogen to fibrin in blood vessels. This fact is used in the diagnostics of VTE. It is a relatively common practice to exclude deep vein thrombosis and pulmonary embolism on the basis of D-dimer levels below $0.5 \mu \mathrm{g} / \mathrm{mL}$. High serum D-dimer levels are a compelling indication for further diagnostic test for VTE. Some authors indicate that D-dimer levels correlate with future development of deep vein thrombosis [27, 28]. At this point, it is important to consider other conditions that may lead to elevated D-dimer levels, such as chronic inflammation, malignancies, injuries, and pregnancy $[27,29]$. The key advantages of a D-dimer test are its simplicity, rapidity, and low cost; while its key disadvantage is its low specificity in the clinical conditions mentioned above [27, 28].

The effect of glucocorticoids (GC) on D-dimer levels has been already reported. Brotman et al. demonstrated an increase in D-dimer following short-term treatment with dexamethasone in healthy volunteers [30].

Our prospective study showed D-dimer levels in patients with $\mathrm{CD}$ to be significantly higher than those in a sex- and age-matched control group. However, the available literature on the subject is scant. A prospective study by Manetti et al. also demonstrated elevated D-dimer levels in the group of patients with hypercortisolism in comparison to those in healthy individuals. D-dimers were not separately analysed or discussed in this work, and the study group comprised both patients with CD and those with Cushing's syndrome caused by cortisol-producing adrenal tumours [9]. Conversely, a study by Fatti et al. in a small heterogeneous patient population with Cushing's syndrome of various origin showed no significant difference between D-dimer levels in the CD group and the healthy control [13].

A retrospective uncontrolled study by Fukuoka et al. in patients with $C D$, adrenal adenomas, ectopic ACTH secretion demonstrated a correlation between Ddimer levels of $\geq 2.6 \mu \mathrm{g} / \mathrm{dL}$ and a high risk of deep vein thrombosis in patients with hypercortisolaemia. This value is lower than the D-dimer level associated with elevated risk of deep vein thrombosis in the general Japanese population. It was explained as a possible effect of plasminogen activation inhibitor 1 (PAI-1), whose concentration in hypercortisolaemia may be higher, leading to inhibition of fibrinolysis and slightly lower generation of D-dimers in Cushing`s syndrome [12].

Moreover, the study by Fukuoka et al. showed a positive correlation between plasma D-dimer levels/ /serum cortisol levels both in the morning and late evening. The authors observed also a correlation between higher cortisol levels following a low-dose dexamethasone suppression test (LDDST) and higher plasma D-dimer levels [12]. Our study did not confirm the correlation between serum cortisol or urinary free cortisol and D-dimer levels. Admittedly, we did not routinely conduct the LDDST $(4 \times 0.5 \mathrm{mg}$ dexamethasone for two days) in favour of an overnight 1-mg dexamethasone suppression test (ODST). There was also no observable association between post-ODST serum cortisol and plasma D-dimer levels. The findings yielded by our version of the dexamethasone suppression test are not consistent with Fukuoka's et al. conclusion (the cortisol secretion autonomy having a more pronounced effect on D-dimer levels and thrombus formation than absolute serum cortisol levels). Such a bold conclusion seems also to be contradicted by the commonly observed very high variability of serum cortisol levels both in normal conditions and in dynamic testing, especially in a highly heterogeneous group of patients with Cushing's syndrome of various aetiologies, which affects the level of cortisol suppression in LDDST. Moreover, apart from serum cortisol levels, the glucocorticoid receptor density also supposedly affects the biological effects of cortisol (including coagulation and fibrinolysis), and it would only be the combination of these two factors that would determine that biological effect.

Our study demonstrated a positive correlation between D-dimer levels and both patient age and hsCRP levels in patients with CD. This is consistent with earlier reports on the correlation of age and inflammation severity on one hand and D-dimer levels on the other, as demonstrated in non-CD populations [25, 27, 31].

Another important finding of our study was that patients with early remission of hypercortisolaemia did not show a decrease in D-dimer levels at three or six 
months following a successful transsphenoidal resection of a corticotroph pituitary tumour. In fact, three months after surgery serum D-dimer levels were found to be higher than in the preoperative period, while six months after surgery they returned to preoperative levels. Additionally, both at three and six months after surgery, D-dimer levels in the remission group were significantly higher compared to the control group. Unfortunately, there are few well-designed prospective studies on this subject. Persistently elevated plasma D-dimer levels following surgical treatment in a heterogeneous group of patients with Cushing's syndrome were demonstrated by Manetti et al.; however, the authors did not discuss D-dimers specifically [9]. This finding may suggest a state of thrombotic readiness and secondary activation of fibrinolysis (as evidenced by D-dimer levels) persisting for six months in the remission group, despite serum cortisol and urinary free cortisol being lowered, even down to subnormal levels. This fact seems to indicate a need for closer patient monitoring for signs of VTE or pulmonary embolism at postoperative follow-up visits. In some cases, imaging studies, such as lower-extremity deep vein ultrasonography, may be considered. We would like to emphasise that there are no specific guidelines for diagnostic and therapeutic management of CD patients, and the formulation of such guidelines would require studies in a larger patient group to include both thromboembolic risk factor evaluation and imaging studies.

\section{Conclusions}

In conclusion, our study demonstrated persistently higher levels of both fibrinogen and D-dimers for a period of at least six months following an initially successful surgical treatment for $C D$, compared with controls. This seems to indicate a need for a closer postoperative follow-up for signs of cardiovascular and thromboembolic complications in patients with early CD remission.

A concomitant comprehensive approach to other established modifiable cardiovascular risk factors seems to be also advisable, in order to improve prognosis. However, the formulation of guidelines for extended anti-thrombotic prevention even after a successful pituitary corticotroph tumour resection requires larger, multicentre, prospective clinical studies involving imaging diagnostics. This may allow us to determine the actual rates of VTE, and possibly to establish the CDspecific cut-off point for D-dimer levels and/or other haemostasis parameters associated with a higher risk of deep vein thrombosis and/or pulmonary embolism.

\section{References}

1. Nieman LK, Biller BMK, Findling JW et al. The diagnosis of Cushing's syndrome: an endocrine society clinical practice guideline. J Clin Endocrinol Metab 2008; 93: 1526-1540.

2. Guignat L, Bertherat J. The diagnosis of Cushing`s syndrome: an Endocrine Society Clinical Practise Guideline: commentary from a European perspective. Eur J Endocrinol 2010; 163: 9-13.

3. Zada G. Diagnosis and multimodality management of Cushing's disease: A practical review. Int J Endocrinol 2013; 2013: 893781.

4. Witek P, Zieliński G, Maksymowicz M et al. Cushing's disease - assessing the efficacy of transsphenoidal surgery. Endokrynologia Polska 2012; 63: 398-404.

5. Tung SC, Wang PW, Liu RT et al. Clinical characteristics of endogenous Cushing's syndrome at a medical center in southern Taiwan. Int J Endocrinol 2013; 2013: 685375 .

6. Witek P, Zieliński G, Szamotulska K et al. Complications of Cushing's disease - prospective evaluation and clinical characteristics. Do they affect the efficacy of surgical treatment? Endokrynol Pol 2012; 63: 277-285.

7. Patil GC, Prevedello DM, Lad SP et al. Late recurrences of Cushing's disease after initial successful transsphenoidal surgery. J Clin Endocrino Metab 2008; 93: 358-362.

8. Colao A, Pivonello R, Spiezia S et al. Persistence of increased cardiovascular risk in patients with Cushing `s disease after five years of successful cure. J Clin Endocrinol Metab 1999; 84: 2664-2672.

9. Manetti L, Bogazzi F Giovannetti C et al Changes in coagulation indexes and occurrence of venous thromboembolism in patients with Cushing's syndrome: results from a prospective study before and after surgery. syndrome: results from a prospective
Eur J Endocrinol 2010; 163: 783-791.

10. Van Zaane B, Nur E, Squizzato A et al. Hypercoagulable state in Cushing's syndrome: a systematic review. J Clin Endocrinol Metab 2009; 94: $2743-2750$.

11. van der Pas R, de Bruin C, Leebeek FW et al. The hypercoagulable state in Cushing's disease is associated with increased levels of procoagulant factors and impaired fibrinolysis, but is not reversible after short-term biochemical remission induced by medical therapy. J Clin Endocrinol biochemical remission induce

12. Fukuoka H, Takeuchi T, Matsumoto R et al. D-dimer as a significan marker of deep vein thrombosis in patients with subclinical or overt Cushing's syndrome. Endocrine J 2014; 61: 1003-1010.

13. Fatti LM, Bottasso B, Invitti C et al. Markers of activation of coagulation and fibrinolysis in patients with Cushing's syndrome. J Endocrinol Invest 2000; 23: 145-150.

14. Boscaro M, Sonino N, Scarda A et al. Anticoagulant prophylaxis mark edly reduces thromboembolic complications in Cushing's syndrome. J Clin Endocrinol Metab 2002; 87: 3662-3666.

15. White RH, Zhou H, Romano PS. Incidence of symptomatic venous thromboembolism after different elective or urgent surgical procedures. Thromb Haemostas 2003; 90: 446-455.

16. White RH, Romano PS, Zhou H et al. Incidence and time course of thromboembolic outcomes following total hip or knee arthroplasty. Arch Int Med 1998; 158: 1525-1531.

17. Miljic P, Miljic D, Cain JW et al. Pathogenesis of vascular complication in Cushing's syndrome. Hormones (Athens) 2012; 11: 21-30.

18. Ernst E, Resch KL. Fibrinogen as a cardiovascular risk factor: a metaanalysis and review of the literature. Ann Int Med 1993; 118: 956-963.

19. Ernst E, Matrai A, Marshall M. Blood rheology in patients with transient ischemic attacks. Stroke 1988; 19: 634-636.

20. Coull BM, Beamer N, de Garmo P et al. Chronic blood hyperviscosity in subjects with acute stroke, transient ischemic attack, and risk factor for stroke. Stroke 1991; 22: 162-168.

21. Letcher RL, Chien S, Pickering TG et al. Direct relationship between blood pressure and blood viscosity in normal and hypertensive subjects. Role of fibrinogen and concentration. Am J Med 1981; 70: 1195-1200.

22. Stec JJ, Silbershatz H, Tofler GH et al. Association of fibrinogen with cardiovascular risk factors and cardiovascular disease in the Framingham Offspring Population. Circulation 2000; 102: 1634-1638.

23. Aleman MM, Walton BL, Byrnes JR et al. Fibrinogen and blood cells in venous thrombosis. Thromb Res 2012; 133: S38-S40.

24. Erem C, Nuhoglu I, Yilmaz M et al. Blood coagulation and fibrinolysis in patients with Cushing's syndrome: increased plasminogen activator inhibitor-1, decreased tissue factor pathway inhibitor, and unchanged inhibitor-1, decreased tissue factor pathway inhibitor, and unchanged 2012; 32: 169-174.

25. Emerging Risk Factors Collaboration, Kaptoge S, Di Angelantonio E Pennells L et al. C-reactive protein, fibrinogen, and cardiovascular disease prediction. N Engl J Med 2012; 367: 310-320.

26. Berk BC, Weintraub WS, Alexander RW. Elevation of C-reactive protein in "active" coronary artery disease. Am J Cardiol 1990; 65: 168-172.

27. Cushman M, Folsom AR, Wang L et al. Fibrin fragment D-dimer and the risk of future venous thrombosis. Blood 2003; 101: 1243-1248.

28. Tripodi A. D-dimer testing in laboratory practice. Clin Chem 2011; 57: 1256-1262.

29. Ay C, Dunkler D, Pirker R et al. High D-dimer levels are associated with poor prognosis in cancer patients. Haematol 2012; 97: 1158-1164.

30. Brotman DJ, Girod JP, Posch A et al. Effects of short-term glucocorticoids on hemostatic factors in healthy volunteers. Thromb Res 2006 118: $247-252$

31. Righini M, Van J, Den Exter PL et al. Age-adjusted D-dimer cutoff level to rule out pulmonary embolism: the ADJUST-PE study. JAMA 2014; 311: $1117-1124$ 